
総
説

\title{
義歯床用軟質裹装材
}

早川䊊

東京医科歯科大学大学院医歯学総合研究科 1 腔機能再構築学系 摄食機能回復学講座 掑食機能評価学分野

(2001 年 9 月 28 日受付)

\section{Denture Soft Lining Materials}

Iwao Hayakawa

Department of Masticatory Function Rehabilitation, Division of Oral Health Sciences, Graduate School,

Tokyo Medical and Dental University

\section{I 。はじめに}

顎堤の吸収の著しい症例では, 满足に咀嚼できる義㐘 を製作することは難しいものである。印象採得時に積極 的に義歯床面積の拡大を四り，顎堤の単位面積当たりの 圧負担を少なくしたり，咬合面を小さくすることで咀嚼 圧の負担の軽減を図るなどの方策を駆使することでなん とかしのいでいる。しかし, 極端に骨吸収が進み, かつ それに伴って被覆粘膜も非薄化している症例では, 義歯 床下粘膜にショック・アブゾーバーの働きがなくなり, 咬合圧が緩和されることなく直接顎骨に伝えられるの で, 顎堤の負担がさらに增大される。加之て, 硬い義歯 床と弾力性のない歯槽骨との間に挟まれた薄い粘膜は, 咬合する度に絞犺的, 傷つき, 痛みを発すること になる。このように粘膜が非薄な症例では, さらに一歩 進んだ対策を迫られる。すなわち，義歯床内面を粘膜と 類似した軟らかい材料で裏打ちして, 失われた顎堤粘膜 の粘弾性を補い，そのクッション作用で咬合時の衝撃を 緩和し, かつ顎堤全域へ圧力を均等に分散することで疼

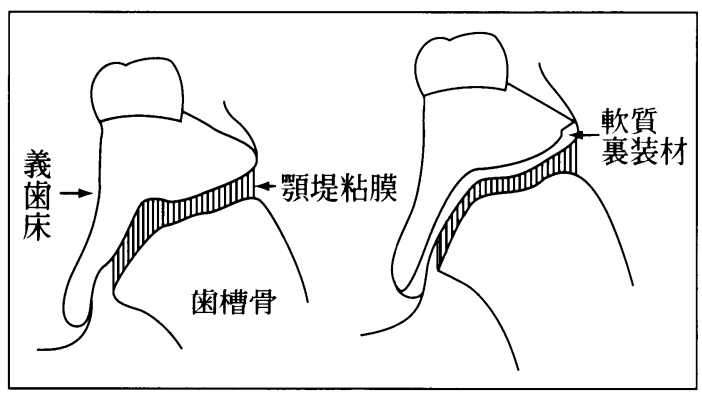

図1失われた粘膜の粘弾性を軟質裏装材で補う。
痛の解消を図らなければならない。この裏打ちに用いる 材料が軟質簑装材である(図 1)。昨今では広く一般に用 いられるようになり，義歯使用時の疼痛緩和を四る有用 な材料として定着してきているようである。

ここでは,当教室で行われてきた研究を紹介しながら， 軟質裏装材の材料, クッション効果と応力の分散, 粘弾 性，そして寒装することによって咀啋機能にどのような 影響が現れるかなども加之, 軟質哀装材について総合的 に考えてみたい。

\section{II. 軟質裏装材の材料}

材料としてアクリル系，シリコーン系，フッ素系，才 レフィン系など多くの樹脂が使用されてきた。現在一般 に用いられている大方の製品は可塑剂添加アクリル樹脂 とシリコーンラバーであるり。ともに加熱重合タイプと 常温重合タイプのものがあり, 症例に応じて間接, 直接 裏装法として使い分けられている。

いずれの材料も材質的にかなり向上してきてはいる が，まだまだ多くの問題点を残している。可塑剂添加ア クリル樹脂はその組成から，アクリル樹脂からなる義歯 床と強固な接着が期待できるが, 吸水性, 溶出量が大き いため変質, 劣化しやすい2)。また添加されている可塑剂 がレジン表面に拡散し唾液中に溶出するので，しだいに 硬くなる3〉。一方，シリコーン系材料は，化学的に安定な 材料で弾性を長く維持するが, アクリル樹脂とは直接接 着しないので，接着戍の使用が不可欠である。この接着 剂についても，最近では接着強さがかなり向上している といわれているが，まだまだ十分とはいえない4,5)。また シリコーンは疎水性材料なので, 吸水量は少ないが, ぬ 


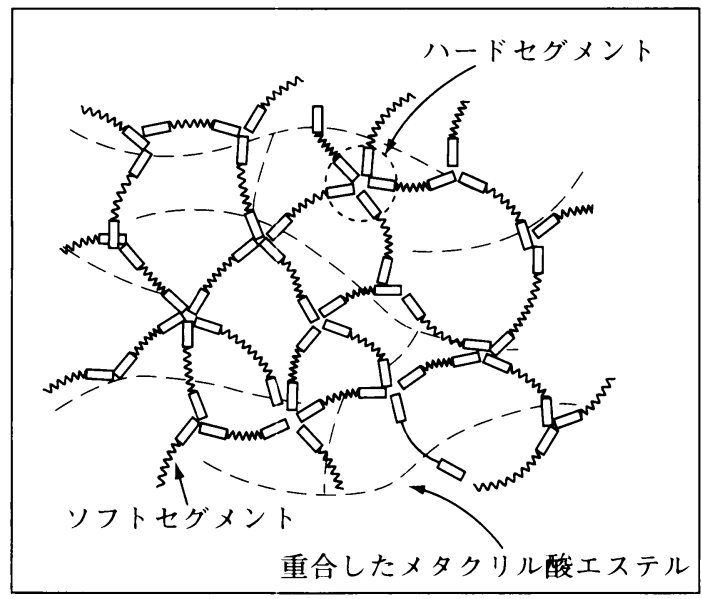

図2 イソプレン系エラストマーを応用した軟質裏装材硬化 物の構造。メタクリル酸エステルの重合は, 架橋構造が緩 やかに形成されるのでイソプレン系エラストマーのクッ ション性を妨げない。

れが悪く顎堤粘膜へのなじみが損なわれる ${ }^{6)}$

これらの問題点を解決するために, 最近イソプレン系 エラストマーを応用した光重合型軟質裏装材が開発され た2,7)。配合されているイソプレン番エラストマーは, ハードセグメントとソフトセグメントからなるブロック コポリマーである。ハードセグメントはセグメント間に 化学的な結合は持たないが，集合しやすい性質を有して いるので，凝集したドメインは架橋点のような機能を持 つ。間に挟まれたビニルイソプレン構造を基本骨格とす るソフトセグメントがエラストマーの軟らかさを担い, 架橋を形成する再末端のハードセグメントが材料の形態 安定性を高める役割を果たしている。新材料はこれらの ポリマーをメタクリル酸エステルモノマーに溶解させて ペースト化したものに, 光重合触媒を配合したものであ る。このペーストを光照射することによりメタクリル酸 エステルが重合硬化し, IPN (Interpenetrating Polymer Network，相互侵入高分子網目)を形成する。このエス テルの重合は, 架橋構造が緩やかに形成されるので, イ ソプレン系エラストマーのクッション効果を妨げること はない(四 2 )。本材料はアクリル系の裏装材に該当する が, 従来のアクリル系材料のように可塑剤が配合されて いないので，可塑剂の溶出にまつわる問題が生じない。 また, 光重合材料なので, 修正を繰り返し, 適切な辺縁 形態が付与されたと判断された後に重合されるので，直 接法で必須とされる重合後の辺縁形態の修正および研磨 の必要がない8

この他にも当教室では，吸水性がきわめて小さく，ア クリル樹脂との接着性が良好で，材質的にも安定した フッ素系の軟質亭装材を開発している ${ }^{9,10)}$ 。広く臨床で用 いられていたが，製造過程で四塩化炭素が使用されてい
たため, 四塩化炭素の禁止に伴い残念ながら製造が中止 されてしまった。

\section{一粘膜調整材一}

粘膜の調整を目的に使用されている Hydro-Cast (Kay-See Dental), Visco-gel(Amalgamated Dental), Fitt (Kerr), Soft Liner (ジーシー), Comfort (Coe) などの粘膜調整材 tissue conditioner も弾性裏装材と一 般にはいわれている。粉末状ポリマーの組成は，ポリメ タクリル酸エチル，あるいはこれを含むコポリマーで， 液状モノマーは芳香族エステルのアルコール溶液であ る。液にはアクリル系モ/マーは含まれていない。両者 を混ぜると可塑性のゲル状となる ${ }^{11)}$

粘膜調整材は，短い期間ではあるがこの可塑性が持続 されるので，使用中の義歯に裏装すれば，義歯の不適合 によって歪んだ粘膜の回復に役立ち，また粘弾性もある のでクッションとして働き，咬合時の疼痛を緩和する効 果もある。しかし，材質的に不安定な高分子の軟質材料 であるので，口腔内で吸水膨潤したり，逆にアルコール などの有効成分が溶出したりして短期間で粘弾性を失っ てしまう。よって，長期間使用すると，硬くなったり， 污染されたりして,かえって粘膜を損傷することになる。 これはあくまでも暫間的に用いる粘膜調整材であり，こ こでいう軟質裏装材とは使用目的が明らかに異なってお り，区別すべきである。

\section{III. クッション効果と応力の分散}

軟質裏装材は，咬合時の衝撃を吸収緩和し，かつ床下 組織に伝えられる応力を分散して疼痛緩和を四る有用な 材料とされている。通常は粘膜がこの役割を担っている が，粘膜が菲薄な症例では軟質亭装材でこの作用を補う ことになる。これらの効果を解明するために, 模型を用 いた実験や有限要素法などが一般に行われてい る ${ }^{12 \sim 14)}$ 。しかし，圧力センサーを使用する模型実験では 義歯床下組織全域の応力分布を測定することができない ということで，最近では有限要素法が広く用いられるよ うになってきた ${ }^{15 \sim 17)}$ 。有限要素法では, 咬合床, 粘膜, 歯槽骨からなる有限要素モデルを構築し, そのモデル上 で力学的状態をシミュレートし, 応力分布, 歪み, 変位 などを算出する。

確かに軟質裏装材は咬合圧が加わったとき変形を起こ し，衝撃力を吸収緩和するクッション効果を持っている が, レジン床と比較すると荷重後に義歯の変位量が増大 し, 支持骨内の応力が増加するとの報告もみられる ${ }^{13)}$ 。骨 内に生じる応力は，骨吸収抢よび顎堤変化を引き起こす

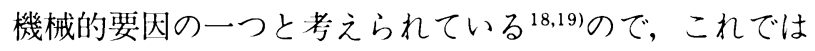
軟質裹装材の使用が擷堤の保全という面からは好ましく ないということになってしまう。このあたりのことを明 
らかにするために当教室では，義歯から粘膜に伝達され る応力を生体環境に近似の条件で解析することを試み た ${ }^{20)}$ 。従来の有限要素法を用いた研究では, 義歯と粘膜, 骨を一体化したモデルを用いた解析がほとんどで，モデ ル上での義歯の挙動は実際の粘膜上で変位する義歯の挙 動と大きく異なっている。口腔内で義歯は粘膜上で唾液 を介して接触しており，力を受けると粘膜上を移動する。 義歯から粘膜に伝達される応力を生体に近い条件で解析 するためには，この義歯の粘膜上での変位をシミュレー トしなければならない。特に，軟質裏装材を使用した場 合には，軟質裏装材自体の変形により義歯の変位も増大 することが予想されるので，義歯床下組織に一層複雑な 影響を及ぼすと思われる。そこで，この義歯床の可動状 態をシミュレートするために，義歯床と粘膜の間に接触 要素として Gap 要素と Truss 要素を挿入し，接触状態 をより生体に近づけることを試みた。接触面に対して垂 直方向に弱いバネのような Gap 要素で連結し，この動き の安定化を直列に連結したTruss 要素で四っている（図 3 )。このモデルを用いて軟質哀装材が義歯床下組織の応 力分布に及ぼす影響を検討した結果，荷重時の床下組織

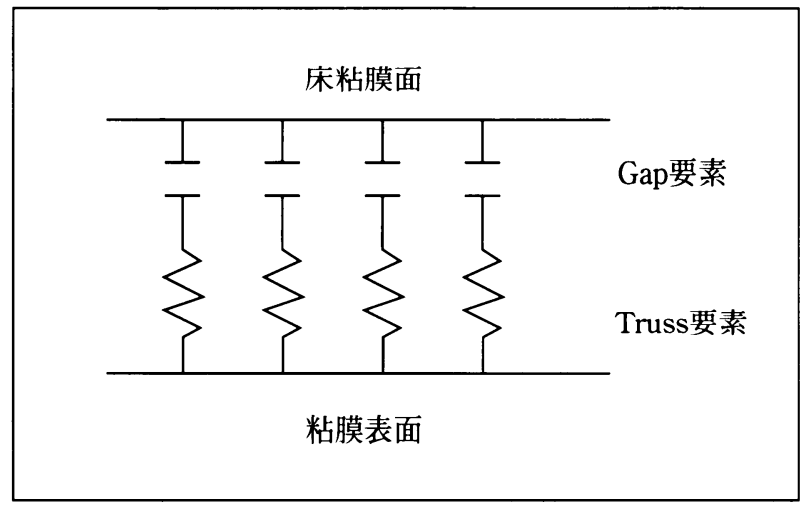

困 3 義㐘床粘膜面と粘膜表面の境界面を構成する Gap 要 素と Truss 要素

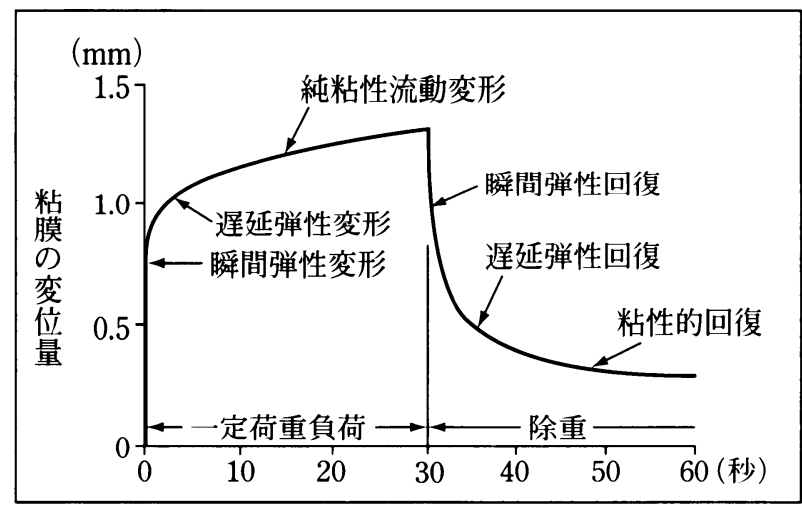

困 4-1 一定荷重した際の粘膜の挙動
において応力の分散効果がみられた。特に皮質骨表面に 分散効果がみられたことより，軟質裏装材の使用が顎堤 保護のためにも有効であることが考えられた。

\section{IV，粘 弾 性}

軟質裏装材は，一般には弾性裏装材 (resilient liner) と呼ばれているが，厳密な意味で真に弾性的な材料とい うことになると，咬合力を受けてそれが除かれる度に義 㐘が顛堤から跳び上がる傾向をもつことになる。粘膜は 粘弹性体であるから，咬合圧で圧縮された粘膜の復元は 徐々にしか起こらないので，咬み込むごとに繰り返し粘 膜に圧接されて半ば粘膜に圧入されたままになり，床の 維持力が持続されることになる。軟質裏装材が顎堤粘膜 のように咬合力を緩和するショック・アブゾーバーの役 目をするには，粘膜と同様に粘弾性的性質をもつことが 必要となる。すなわち，軟質裏装材か咬合圧によって変 形した後の回復の仕方は，瞬間的な弾性回復ではなく， ゆっくりとした回復であるほうが好ましい11,21)。このよ うな観点からみると，シリコーン系樹脂はゴム様の弾性 を有しており，アクリル系樹脂は粘弾性的性質をもって いる ${ }^{22,23)}$ 。しかし，この粘弾性タイプのものについても， 適切な粘弾性について考慮が払われているとはいいがた w。

軟質裏装材に与えるべき性質を探るためには，咬合圧 がかかったときの顎堤粘膜の挙動を明らかにする必要が ある。当教室では，まず固定源が口腔外にある従来の大 型装置を改善し，固定源を歯列に求める小型のクリープ 測定装置を試作した。この装置を用いて，荷重時および 荷重を除去した際のクリープを測定し，特に除重時の粘 膜の回復現象を明らかにした24)。

荷重がかかると，粘膜は直ちに急激な瞬間弾性変形を 起こす。続いて緩やかな遅延弾性変形が起こり, 純粘性 流動変形へと移っていくが，時間とともに変形率は小さ くなっていく。荷重が取り除かれると，圧縮された粘膜

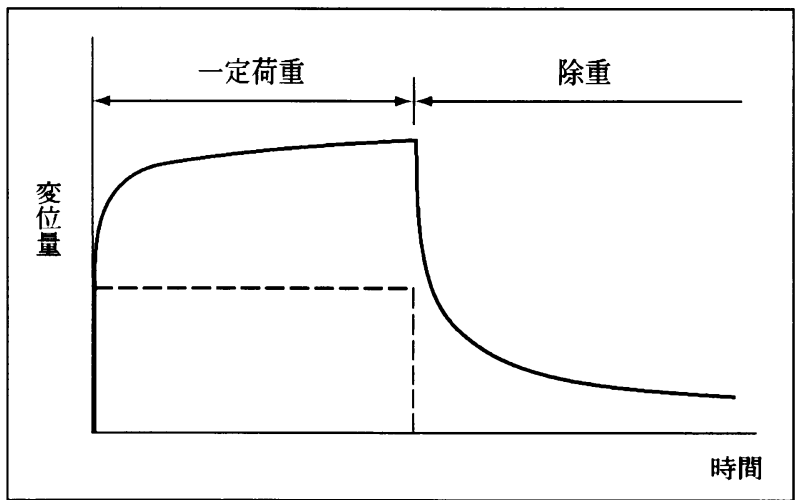

困 4-2 軟質裏装材の荷重負荷挹よび除重時における挙動 (奏線：粘弾性材料，点線：弾性材料) 
の解除が起こる。除重時の回復量については, 瞬間弹性 変形，遅延弾性変形，純粘性流動変形に相当する部分が 観察され，それぞれ荷重時と同様の傾向がみられた（闵 $4-1,4-2)$ 。

次いでこの粘膜の性質を軟質材料で置き換えることが 可能か否かを検討するために，軟質材料を試作し，特に 除重時の挙動が比較された ${ }^{211}$ 。その結果, 架橋剤㧍よび フィラーの量を調節することにより，粘膜の性質に近づ けられることが示唆された。

\section{V．咀礵機能への影響}

前述のように，軟質裏装材は顎堤粘膜が菲薄な症例に おいて咀啷時に生ずる疼痛を緩和する有用な材料として 広く使用されている。確かに具合はいいのだが，通常の 義歯を使用している場合と比較すると，軟質材料を圧縮 するために余分な力を必要とすることが考之られ，これ が咀嚼機能を乱し，かつ筋肉が疲労するのではないかと の不安があった。軟質裏装材を使用した場合，咀嚼筋筋 活動や顎運動に乱れが生じ嵌合位が不安定になるとの報 告もみられる ${ }^{25)}$ 。そこで, 全部床義歯装着者の下顎義㐘を 軟質材料で裏装した際, 咀嚼機能にどのような変化が生 ずるかを検討した ${ }^{26,27) 。 ~}$

咬合力, 咀嚼值, 咀嚼筋の仕事量, 咀嚼リズムなどが 測定，算出され，軟質裏装材の裏装前後で比較された。

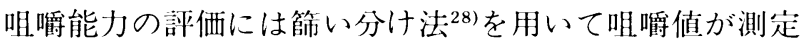
された。またピーナッツ 1 粒を咀䱐させ，嚥下されるま

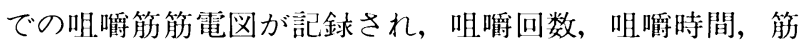
活動量，咀嚼リズムが算出された。ピーナッツ1粒が嚥 下されるまでの筋活動量の総和を仕事量とした。また， 咀徱リズムを評価するために筋放電周期，持続時間，間 隔の変動係数が算出された。その結果，軟質裏装材で裏 装されたことにより, 咬合力, 咀嚼值は增大し, 咀嚼回 数, 時間が減少した。咀嚼リズムも咀嚼の初期から安定 する傾向がみられた。筋活動量の増加はみられず，むし ろ減少する傾向があった。軟質毫装材によって顎堤粘膜 に伝達される咬合压が分散されることで，顎堤がより大 きい咬合力を負担できるようになったと考之られる。ま た，咀嚼中に軟質材料は変形して義㐘をより安定した位 置にシフトすることで咬合のバランスを向上させ，咀嚼 值を増大させていると思われる。咀噃能力が向上したこ とで咀啷回数抢よび咀徱時間が減少した。これらの効果 が咀嚼機能を向上させ，咀嚼筋の仕事量の減少へとつな がったものと思われる。軟質裏装材の使用は，咀喃筋の 仕事量を増加させることなく咀嚼機能を向上させること が示唆された。

\section{VI. 適 応症}

使用にあたっては，軟質材料の助けを借りなければ解 決できない症例か否かを十分に検討してから使用するこ とが大切である。軟質材料を使用すると印象採得や咬合 採得が多少不十分でも，その䛊りが裏装材のクッション で補償される範囲内であれば，カバーされてしまうこと が考えられる。まず，印象採得，咬合採得などの術式に 熟達したうえで，有効に使用されたい。それらの䛊りを 材料で逃げるといjのは, 本筋ではないよjに思われる。 どこかで，そのしわ寄せを受けることにもなる。

適応とされる症例には, 次のよjなものが挙げられる。

1) 顎堤の吸収が著しく, かつ粘膜が菲薄なため, 咀 嚼時に疼痛が発生する症例

2 ）歯槽骨の吸収が不規則であったり，鋭利な骨縁が あり, 咀嚼時に疼痛がある症例

3) 歯槽骨に顕著なアンダーカットが存在する症例

4 ）顎堤の咀嚼圧負担能力が弱く，咬合圧を分散，緩 衝したい症例

5）顎補緅のオブチュレーターの製作

特に禁忌症はないが, 粘膜が厚く, クッション作用の ある症例では，本来の目的から外れるため使用は差し控 えたい。

\section{一棗装法一}

直接法は，裏装材を義歯床粘膜面に盛って口腔内で印 象採得を行い，それをそのまま口腔内あるいは千ェア一 サイドで重合させるので，比較的操作が簡便である。直 接口腔内で操作するので，詥差の入る機会も少ない。し かし，唾液などによる污染を受けやすく，また裏装形態 のコントロールが難しいため, 裏装材として必要な厚さ を確保したり，均一な厚さにすることができない。材質 によっては，未反応モノマーや重合時の発熱などによる 粘膜への刺激も考之られる。理工学的性質も，その性能 は間接法で製作した場合よりも劣っている。したがって, この方法は暫間的な使用を前提とした場合，あるいは患 者の通院に条件のある場合などに限られるべきであろ j。一方，間接法は印象採得を行った後，技工室で裏装 操作を行うもので，ステップは增えるが千ェアータイム は短くなる。しかも，各ステップでの操作を確認しなが ら行えるので，裏装形態や厚さなどをコントロールする ことができる。

\section{VII.おわりに}

高秢化社会を迎えているが，歯の寿命についてはそれ ほど延びがあったとの報告は聞かれないので, 必然的に， 義歯の使用年数だけが増加することになると思われる。 老人特有の口腔内変化に加えて, この義歯使用年数の延 
長は，歯槽骨をはじめ義歯周囲組織にわれわれ歯科医が 今まで経験したこともない変化をもたらすのではないか と恐れている。顎堤状態の悪い症例の増加は想像に難く ない。このような変化に対応するためにも，今後軟質裏 装材の使用頻度はますます增加していくものと思われ る。

しかしながら，現在のところ耐久性の点では義歯床レ ジンのようにはいかない。クッション作用を有している 軟質材料は，ちょうどゴムUもが伸縮を繰り返すと，と ころどころに裂け目ができて伸び切ってしまうように， 使用中の伸縮に起因する材料疲労が避けられない。この 疲労により材料にクラックが生じ，これが污染の原因と なり耐久性を低下させていると思われる。よって，こま めな千ェック，さらには定期的な張り智えなどが必須で ある。より優れた材料の研究，開発が待たれる。

\section{文献}

1) McCabe, J. F. : A polyvinylsiloxane denture soft lining material. J. Dent. 26:521-526, 1998.

2) Hayakawa, I., Keh, E., Morizawa, M., et al. : A new polyisoprene-based light-curing denture soft lining material. J. Dent.：(投稿中).

3) Jones, D. W., Hall, G. C., Sutow, E. J., et al. : Chemical and molecular weight analyses of prosthodontic soft polymers. J. Dent. Res. 70:874-879, 1991.

4) Kutay, O.: Comparison of tensile and peel bond strengths of resilient liners. J. Prosthet. Dent. 71 : 525-531, 1994.

5) O'Brien, W. J. : Dental materials and their selection. Chicago, 1997, Quintessence, 90.

6) Waters, M. G., Jagger, R. G. and Polyzois, G. L. : Wettability of silicone rubber maxillofacial prosthetic materials. J. Prosthet. Dent. 81 : 439-443, 1999.

7）山门里志：イソプレン系エラストマーを応用した義歯床 用軟質裏装材の特長. 増原英一編著, 歯科用接着性レジン と新臨床の展開, 東京, 2001, クインテッセンス出版, $65^{-76 .}$.

8）守澤正幸，早川 嚴：新しく開発された床用軟質重装材 の性質と使用法. 増原英一編著. 歯科用接着性レジンと新 臨床の展開，東京，2001，クインテッセンス出版， 219-230.

9) Hayakawa, I., Kawae, M., Tsuji, Y., et al. : Soft denture liner of fluoroethylene copolymer and its clinical evaluation. J. Prosthet. Dent. 51 : 310-313, 1984.

10）早川嚴, 野村知子, 松井一則, 他：餅状フッ素系軟質裏 装材の開発研究. 補緅誌 $30 ： 321-325,1986$.

11) Phillips, R. W. : Skinner's science of dental materials (ed. 10). Philadelphia, 1996, W. B. Saunders, 264.

12）栄村 勲, 前田芳信, 伊堂寺茂, 他：義歯軟質弾性裏装材 による咬合力の分散に関する実験的検討。阪大歯学誌 37 : 407-411， 1992.

13）河野文昭，浅岡憲三，永尾 莌，他：粘弾性解析による軟 質裹装材の有用性に関する研究一第 1 報 軟質裏装材が 床下組織の忍力分布に及ぼす影響一。補経誌 36 ： 1305-1311, 1992.

14）河野文昭, 永尾 莌, 井上三四郎, 他：粘弾性解析による 軟質裏装材の有用性に関古る研究一第 2 報 軟質裏装材

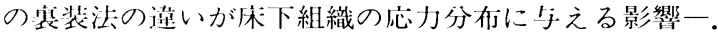
補経誌: 38 : 1328-1335, 1994.

15）田中正夫, 瀬口靖幸：有限要素法の基礎知識と注意点. バ イオメカニズム学会誌 $11 ： 43-51,1987$.

16) Maeda, Y. and Wood, W. W. : Finite element method simulation of bone resorption beneath a complete denture. J. Dent. Res. 68: 1370-1373, 1989.

17）河野文昭，多四 望，永尾 寛，他：粘弾性解析に上る義 㐘床下組織の応力分布一粘弾性解析の導入。補経誌 $34: 623-630,1990$.

18) Cowin, S. C. : Bone remodeling of diaphyseal surfaces by torsional loads: Theoretical predictions. J. Biomecanics 20 : 1111-1120, 1987.

19）前田劣信, 堤 定美, 奥田正俊, 他：有床義歯装着者の省 吸収シミュレーション, 第一報 最適形状決定法の応用. 補緅誌 $33 ： 450-456,1989$.

20）巫 春和：軟質裏装材が床下組織の忍力分布に及ぼす影 響一接触要素を導入した有限要素法。補緅誌 $44: 234$ 243,2000 .

21) Hayakawa, I., Hirano, S., Kobayashi, S., et al. : The creep behavior of denture-supporting tissues and soft lining materials. Int. J. Prosthodont. 7 : 339-347, 1994.

22) Matsumoto, T. and Hayakawa, I. : Study on a light cured soft lining material. International congress on dental materials, transactions : 437-438, 1989.

23) Hayakawa, I. : Principles and practices of complete dentures. Tokyo-Chicago, 1999, Quintessence, 235.

24）平野滋三：П蓋粘膜のクリープの解析一回復時の粘膜の 挙動について一。病誌 59:75-92, 1992.

25）鈴木 潤，長田純一，児玉厚三，他：義歯床用軟質裏装材 が顎口腔系に及ぼす影響について。補緅誌 $33: 489$ ， 1989 .

26）高橋保樹：軟質裏装材の使用が全部床義歯装着者の咀嚼 機能に及ぼす影響。口病誌 $64 ： 518-533 ， 1997$.

27) Hayakawa, I., Hirano, S., Takahashi, Y., et al. : Changes in the masticatory function of complete denture wearers after relining the mandibular denture with a soft denture liner. Int. J. Prosthodont. 13: 227-231, 2000.

28) Manly, R. S. and Braley, L. C. : Masticatory performance and efficiency. J. Dent. Res. $29: 448-462,1950$. 